
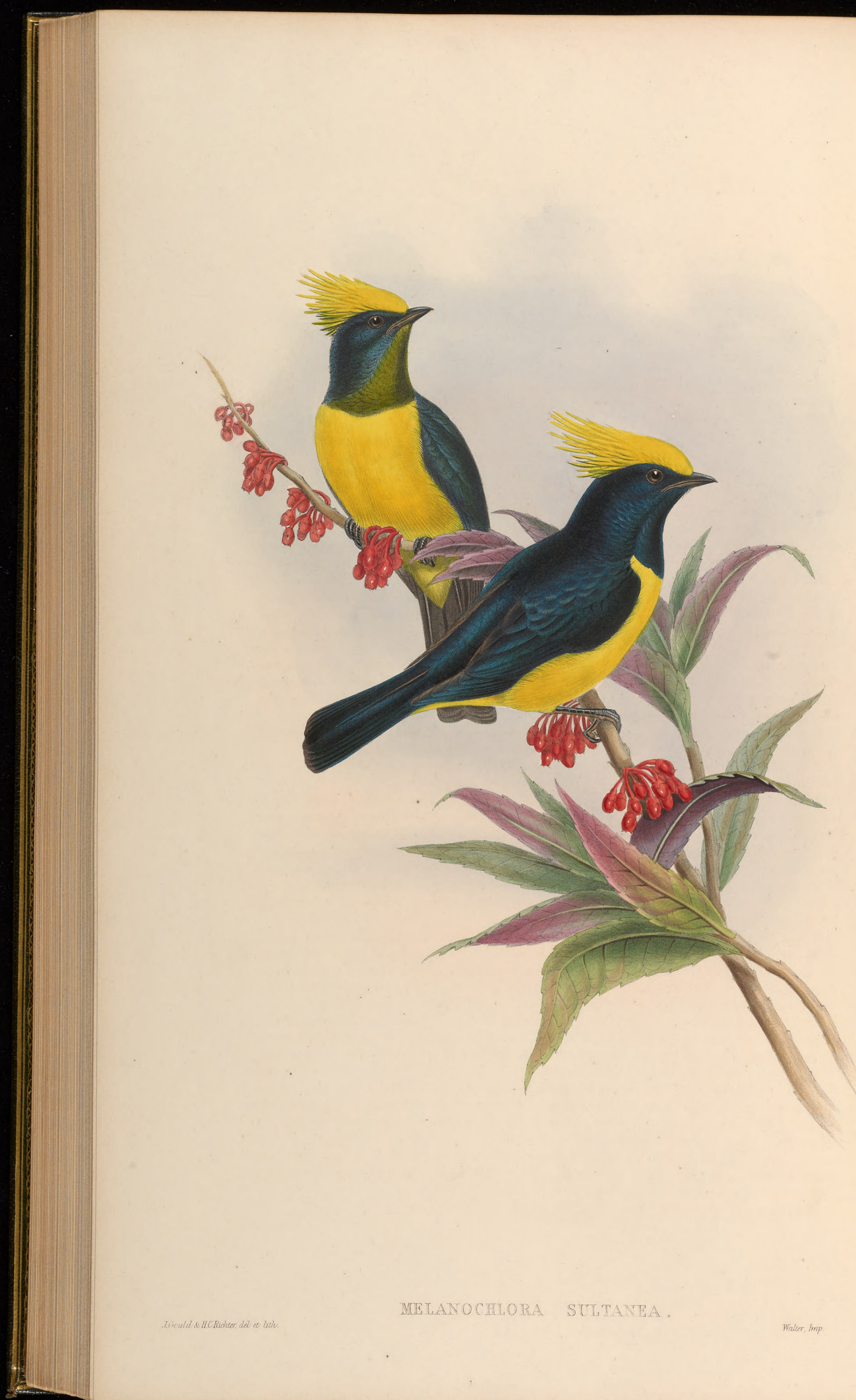


\title{
MELA NOCHLORA SULTANEA.
}

\author{
Sultan Tit.
}

Parus sultaneus, Hodgs. Ind. Rev., 1836, p. 31.-Gray, Zool. Misc., 1844, p. 83.-Blyth, Journ. Asiat. Soc. Beng., vol. xiii. p. 943.-G. R. Gray, Gen. of Birds, vol. i. p. 192, Parus, sp. 41.

- Alavocristatus, Lafres. Mag. de Zool., 1837, Ois. pl. 80.-Horsf. in Proc. of Zool. Soc. (1839), p. 162.Blyth, Journ. Asiat. Soc. Beng., vol. xi. p. 184, and vol. xii. p. 955.-Id. Cat. of Birds in Mus. Asiat. Soc. Calcutta, p. 102.-Id. in Jard. Cont. to Orn., 1852, p. 48.

Melanochlora Sumatrana, Less. Rev. Zool., 1839, p. 42. sultaneus et flavocristatus, Bonap. Consp. Gen. Av., tom. i. p. 333

Parus Sumatranus, Blyth, Journ. Asiat. Soc. Beng., vol. xi. p. 792

Crataionyx flava et ater, Eyt. Proc. of Zool. Soc. (1839), p. 104.

Melanochlora sultanea, Jerd. Birds of Ind. vol. ii. pt. 1. p. 282.-Wald. in Proc. of Zool. Soc. (1866), p. 551.Bon tylia pho, Lepchas (Jerdon).

Ornithologists very generally agree in placing this bird among the Parida, and Strickland went so far as to say he considered it a typical Tit; but in my opinion we ought first to define the characters of the family, and then determine whether such birds as those forming the genera Agithalus and Calamophilus on the one hand, and Falcunculus on the other, are members of it; if so, then Melanochlora may not be too widely different to be admitted also. For myself, I am sure that a mere glance at the accompanying. Plate will be sufficient for even an ordinary observer to perceive how greatly the birds figured thereon differ from the ordinary Tits. The small amount of information that has been recorded respecting their habits and economy throws but little light on the subject : they are said to frequent the tops of large trees, and to move about in flocks; the reed-loving Calamophilus is equally gregarious, yet it is by many writers excluded from the Paridce. Besides this difficulty as to the affinities of Melanochlora, it is a question whether there are one or two species of this form, or if the Malaccan and Sumatran birds be identical with those from the Himalayas. It will be seen, from the synonyms given above, that I regard them as one and the same; but I must remark that my figures were taken from Himalayan specimens, which are always larger and more beautifully coloured than those from Sumatra.

As is the case with the members of the genus Falcunculus, a marked difference occurs in the ontward appearance of the sexes, the female having the throat green, while in the male it is steel-blue.

The following short sentences, which are given with due acknowledgment of the sources whence they were obtained, comprise all that has been recorded respecting this showy bird :-

"This magnificent Tit," says Mr. Jerdon, " is only found in the warmer valleys of the Himalayas, extending into Assam, and through Burmah to the Malayan peninsula, and even to Sumatra. Near Darjeeling it is common in the valley of the great Runjeet, about 1200 feet, and thence ascends to about 4000. It frequents the tops of high trees, in small flocks, feeding on insects chiefly, and emits a rather loud note. The Lepchas told me that it breeds in holes in lofty trees, but did not obtain me the nest and egg.s."

Mr. Hodgson states that " it is found in the northern regions of the hills, passing into the southern in winter. It explores foliage, and feeds upon the softer arboreal insects, perfect and imperfect, is exceedingly fond of caterpillars, and occasionally takes pulpy berries."

Captain Beavan, who obtained a specimen at Kyodan, Salween River, Burmah, on the 14th of August, 1865, states that the species there "occurs in small parties in heavy tree jungle, and is very noisy." Viscount Walden, in his Notes on the Birds collected by Capt. Beavan in Tenasserim and in the Andaman Islands, remarks, on the above-mentioned specimen, that it is "a young male in immature plumage, the yellow crest hardly extending beyond the nape, and the dark portion of the plumage being of a dull greenish brown," and adds, "Specimens from Penang and Darjeeling do not differ; and the geographically intermediate Tenasserim race seems to be identical with them. I adopt Mr. Hodgson's designation in preference to that of Lafresnaye, on the authority of the date cited by Dr. Jerdon. Sumatran examples have yet to be compared with continental, and, if found to be specifically distinct, will have to take Lafresnaye's title of flavo-cristatus. Prince Bonaparte, in his 'Conspectus Generum Avium,' keeps the two separate, but gives no other distinction than that of size, Hodgson's species being, according to him, the smallest. This statement, however, is not quite reliable; for the Prince records them both from the Himalayas." (Proc. of Zool. Soc. 1866, p. 551.)

The male has the forehead, crown, lengthened crest, under wing-coverts, breast, abdomen, flanks, and under tail-coverts pure yellow; the remainder of the plumage black, glossed with green on the throat; irides dark brown; bill and feet greenish black.

The figures represent the two sexes, of the size of life, on the Epigynium acuminatum. 


\section{$2 \mathrm{BHL}$ Biodiversity Heritage Library}

Gould, John. 1868. "Sultan Tit, Melanochlora sultanea [PI. 51]." The Birds of Asia 2(XX), -. https://doi.org/10.5962/p.323393.

View This Item Online: https://www.biodiversitylibrary.org/item/118636

DOI: https://doi.org/10.5962/p.323393

Permalink: https://www.biodiversitylibrary.org/partpdf/323393

\section{Holding Institution}

Smithsonian Libraries

\section{Sponsored by}

Smithsonian Institution Libraries

\section{Copyright \& Reuse}

Copyright Status: Not in copyright

This document was created from content at the Biodiversity Heritage Library, the world's largest open access digital library for biodiversity literature and archives. Visit BHL at https://www.biodiversitylibrary.org. 